\title{
From Exclusivism to Inclusivism in Jewish Prayers. The Case of the Morning Prayer: Blessed are You, Lord, for Not Having Made Me a Woman
}

\author{
Shoshana Ronen \\ Hebrew Studies Department \\ University of Warsaw \\ ronen@uw.edu.pl
}

\begin{abstract}
Jewish prayers and holy texts of religious rituals contain messages which are, from a contemporary point of view, highly exclusive and discriminating. However, Judaism treats its texts as sacred, bestowed directly from God, and therefore, unchangeable. Jewish Orthodoxy refuses to alter even one letter in the traditional texts. Nevertheless, since the reformation of Judaism in the mid-nineteenth century in Germany, and particularly since the mid-twentieth century in the USA, liberal and progressive Jewish communities have come to the conclusion that human dignity is more important than faithfulness to old texts, and therefore some changes have to be made. These have usually been slight alterations which eliminated exclusive and belittling meanings from the original text. Today, even Orthodox Jews feel unease with this situation, and are considering different solutions. The article deals with the case of the morning prayer "Blessed are You, Lord, for Not Having Made Me a Woman" and its interpretations and modifications from the Middle Ages to modern times.
\end{abstract}

Keywords: Judaism, Orthodoxy, liberal Judaism, prayers, morning blessings, women Słowa kluczowe: judaizm, ortodoksja, liberalny judaizm, modlitwa, poranne błogosławieństwo, kobiety

Jewish prayers and holy texts of religious rituals, texts and fragments which are repeated constantly on the Sabbath, on holidays, and even every morning, contain messages which are, from a contemporary point of view, highly exclusive, discriminating and affronting. However, Judaism treats its texts as sacred, bestowed directly from God, and therefore unchangeable. Jewish Orthodoxy refuses to alter a word, even one letter, in the traditional texts, and even more liberal Jewish trends (e.g. Conservative 
Judaism, Neo-Orthodox communities) tend to keep the original texts as they were written about two thousand years ago. Nevertheless, since the reformation of Judaism in the mid-nineteenth century in Germany and, particularly, since the mid-twentieth century in the USA, liberal and progressive Jewish communities have come to the conclusion that, with all due respect and faithfulness to the old texts, the idea of human dignity is more important, and therefore some changes should be made. Usually these have been slight alterations which removed exclusive and belittling meanings from the original text. In this essay, I would like to discuss some of the morning prayers (Birkhot Ha-shachar), their problematic formulation, and the intra-Jewish debate over their various versions.

\section{What are the morning prayers?}

The morning prayers are a list of blessings which every Jew should recite shortly after waking up in the morning. The text was probably first an idiom or a maxim, but once it was included in the rabbinic texts the door was open for its canonisation, and the blessings were added to the morning prayers. ${ }^{1}$ As a prayer, it was first uttered in solitude at home, but with time it was included in the Jewish liturgical canon and became a part of the morning service in the synagogue.

The first part of the morning prayers is constructed from a list of blessings in which Jews thank God for renewal of the day, and then, in minute detail, thank for their body's well-functioning, and also for the reunion of the body with the soul. According to Jewish belief, while sleeping, the soul departs the body, and upon awaking the body and the soul are reunited. The idea behind these blessings, which are, in fact, an expression of gratitude towards the Lord, is that each tiny detail of human life has a divine value, and is the outcome of God's good will.

From all the morning blessings, I would like to recount only three, and thereafter concentrate on one. The three blessings are: 1. Blessed are You, Lord, King of the universe, for not having made me a non-Jew; 2. Blessed are You, Lord, King of the universe, for not having made me a slave; 3. Blessed are You, Lord, King of the universe, for not having made me a woman. For the third blessing, women have a different version, reciting: Blessed are You, Lord, King of the universe, for having made me according to His will. ${ }^{2}$ These three benedictions are, in fact, a declaration of selfidentity and the position of a person in the world ${ }^{3}$ by excluding undesirable religion, ethnic, class and gender belonging. Yoel Kahn rightly calls this "defining oneself

${ }^{1}$ Y.H. Kahn, The Three Blessings: Boundaries, Censorship, and Identity in Jewish Liturgy, Oxford 2011, pp. 13, 17, 201.

${ }^{2}$ The origin of the women's version is much later, and the first references are from as late as the thirteenth century. See: G. Zivan, 'Shelo asani isha've 'she'asani kirtsono': hatsa'a livrakha aheret [in:] Jewish Legal Writings by Women, M.D. Halpern, C. Safrai (eds.), Jerusalem 1998, pp. 8-10.

3 J. Tabory, The Benedictions of Self-Identity and the Changing Status of Women and of Orthodoxy [in:] Kenishta: Studies of the Synagogue World, J. Tabory (ed.), Bar-Ilan 2001, p. 107. 
against the other." ${ }^{4}$ The source for the blessings is pre-Talmudic, and throughout the ages it has undergone modifications, having many linguistic formulations, ${ }^{5}$ although these are rather similar in meaning. Because the subject in question is inherently an oral tradition, it is impossible to date the first version of this text, but Jewish written sources included it around the second century, ${ }^{6}$ and afterwards it also appeared in the Babylonian Talmud. ${ }^{7}$ This Talmudic version says: (Blessed are You, Lord, King of the universe) who has made me an Israelite, who did not make me a woman, who did not make me a boor. ${ }^{8}$ Some debates of rabbis in the Talmud, and later on, held the idea that women are in fact inferior to men, and the status of women and slaves is the same. Therefore, when a man utters a blessing for not having been made a woman and a slave this is one and the same thing. While a slave is subordinate to his master, a woman is subordinate to her husband. It is not clear whether this approach reflected the historical and the sociological status of women, or is a metaphysical and essentialist worldview, in which women are inferior intrinsically. ${ }^{9}$ Despite the different versions, many rabbis, from the sages of the Talmud, via Maimonides, to Orthodox rabbis today, have claimed that the canonised version in the siddur - the Jewish prayer book, like any other sacred text of Judaism, should not be modified. ${ }^{10}$

Yoel Kahn, who explored the history of these blessings, points to fascinating parallels with Zoroastrian Persian tradition as well as Greek tradition, in which this saying was related to Thales and Socrates. One might name it a circulation of oral traditions, or zeitgeist; in any case, the parallel to the Greek is intriguing. Jews and Jewish ideas were always in contact and mutual influence with the surrounding cultures, and particularly with Hellenistic culture. The three Greek blessings, which also have different versions, articulated gratefulness for the following: "that I was born a human being and not one of the brutes; that I was born a man and not a woman; and that I was born a Greek and not a barbarian." 11 Perhaps Paul rejected this zeitgeist of inter-human distinctions with his well-known words from Galatians 3:28: "There is neither Jew nor Greek, there is neither slave nor free, there is no male and female." 12

Of the three morning blessings, I would like to concentrate on one. The blessing that only men utter every morning of their life from the age of thirteen, thanking God for not being made a woman - shelo asani isha.

\footnotetext{
${ }^{4}$ Y.H. Kahn, The Three Bressings..., op. cit., p. 9.

5 Ibidem, pp. 3-4.

${ }^{6}$ Ibidem, p. 10.

${ }^{7}$ For the Talmudic sources of the blessing see: G. Zivan, op. cit., pp. 6-10.

${ }^{8}$ kodashim: menahot 43b. שעשאני ישראל שלא עשאני אשה שלא עשאני בור.

${ }^{9}$ G. Zivan, op. cit., p. 7.

${ }^{10}$ S. Riskin, Birkat 'shelo asani isha', efsharuyot leshinuy [in:] Lihiyot isha yehudiya, M. Shilo (ed.), Jerusalem 2001, pp. 146-148 (Hebrew).

${ }^{11}$ Y.H. Kahn, The Three Bressings..., op. cit., pp. 9-10.

${ }^{12}$ Ibidem, p. 14.
} 


\section{Rationalisations of the blessing}

The blessing, as it appears today in the Orthodox prayer book, is the one in which a man thanks God "for not being made a woman." This negative formulation might be understood as deriving from the belief that women are inferior creatures, or at least from the observation that they are unprivileged persons. This is no wonder, considering the status that women have long held in many cultures, including the Jewish tradition. Since the status of women in Judaism is not the subject of this essay, I would just like to note the fact that Jewish tradition does not recognise gender equality, and that over the centuries "women have not participated in shaping norms that have governed their lives." ${ }^{\prime 3}$ Women's voices, experiences, and views were never taken into consideration; rather, they were subordinated to men (fathers, husbands), who determined their way of life. ${ }^{14}$ Moreover, Jewish canonical texts, Jewish thinking, Jewish daily life, and religious rituals are founded on a clear distinction between the sexes, and on a hierarchical social structure. This is a gendered structure according to which men have legal superiority and women are excluded from studying, from synagogue services, and from the public sphere as a whole. Women's place is at home in the private sphere. ${ }^{15}$

In contrast to the male version of the morning blessing, the female version has a positive structure: "for having made me according to His will." These words do not express a burst of vital and joyful celebration of who the person is, but rather a humble acceptance of God's will, acknowledging and justifying the verdict. A heartbreaking testimony by Rabbi Baruch Epstein ${ }^{16}$ tells of how his devoted and erudite aunt, Rayna-Batya Berlin, the granddaughter of the eminent Rabbi Hayim of Volozhin, ${ }^{17}$ was deeply hurt and humiliated by this blessing, which she had to utter each and every day of her life, and how she was hurt and upset by the inferior status of women in Judaism. ${ }^{18}$ Rabbi Epstein wrote in his memoir:

How bitter was my aunt that, as she would say from time to time, "every empty-headed, ignorant man," every ignoramus who hardly knew the meaning of the words and who would not

${ }^{13}$ R. Elior, Blessed Art Thou, Lord our God, Who Hast Not Made Me a Woman [in:] Men and Women: Gender, Judaism and Democracy, R. Elior (ed.), Jerusalem 2004, pp. 81-83. Many books were dedicated to the question of Judaism and gender. Among the most important see: B. Greenberg, On Women and Judaism: A View from Tradition, Philadelphia 1981; On Being a Jewish Feminist, S. Heschel (ed.), New York 1983; J. Plaskow, Standing Again at Sinai, New York 1990; T. Ross, Expanding the Palace of Torah: Orthodoxy and Feminism, New Hampshire 2004.

${ }^{14}$ R. Elior, Baruch ata adonai elohenu melekh ha-olam shelo asani isha, "Ravgoni" 2000, no. 3, pp. 30-31 (Hebrew).

${ }^{15}$ O. Tsarfati, D. Liran-Alper, Baruch shelo asani isha? Nitsane si'ah nashi-feministi baitonut haharedit ha-misharit, "Kesher" 2010, no. 40, pp. 127-128 (Hebrew). The authors reveal minor changes in today's ultra-Orthodox community regarding the place and roles of women.

${ }^{16}$ A Lithuanian rabbi and commentator of the Torah. The author of Torah Temimah (Bobruisk 1860Pinsk 1941).

${ }_{17}$ A disciple of Vilna Gaon, the founder of the Volozhin Yeshiva (Volozhin 1749-Volozhin 1821).

${ }_{18}$ J. Tabory, op. cit., p. 131. On the life of this woman see: H. Kehat, Haye'ha ha-meyusarim shel Rayna-Batya Berlin, http://www.old.kolech.org.il/maamar/page/36/ [access: 15.04.2017] (Hebrew). 
dare to cross her threshold without first obsequiously and humbly obtaining her permission, would not hesitate to boldly and arrogantly recite to her face the blessing of shelo asani isha. Moreover, upon his recitation of the blessing, she was obliged to answer "Amen." "And who can muster enough strength," she would conclude with great anguish, to hear this eternal symbol of shame and embarrassment to women? ${ }^{19}$

However, it was not only women who felt deeply wounded by the blessing; ${ }^{20}$ rabbis too felt unease regarding the phrasing. The Orthodox rabbi Avraham Weiss, for instance, admits that when he had to teach the blessings he could not avoid the feeling that he was acting against his own belief: "I did somersaults to explain this phraseology, especially the last one - "who has not made me a woman." ${ }^{21}$ However, this unease is not a new phenomenon, and is not only a reaction of modernised or reformed Judaism. As early as the fourteenth century, Rabbi David Abudirham from Spain, a commentator of Jewish liturgy in the synagogue's service, was troubled with the men's blessing and tried to find an explanation to clarify it. Abudirham claimed that a man should thank God for not making him a woman because as a man he should fulfil much more mitzvoth - precepts, deeds commanded by God - than a woman.

In Jewish tradition, women are exempted from many commandments. Every male Jew is obliged to observe 613 Mitzvoth given in the Torah. There are several categories for these commandments. What is important for us in this context is what is called "time-determined positive commandments" - namely the commandments that a Jew should observe at a fixed time of the day, such as "to lay phylacteries," or special rituals during Shabbat or holidays. Women are exempted from various time-determined mitzvoth because of "domestic peace." If women had to fulfil all the mitzvoth, then they would neglect their obligations at home due to a lack of time. If a woman neglects her domestic duties, then she is not the perfect housekeeper, and consequently might disturb marital harmony. ${ }^{22}$ What is important in this argument is the claim that men are grateful for not having been made a woman because they have the privilege to fulfil more mitzvoth. They have that privilege because they have time, since they have no responsibilities at home. They also treat this obligation not as a burden but as a precious mission. However, if this is the case, then why is the men's blessing not expressed in positive terms - "for having made me a man" - but rather in negative ones - "for not having made me a woman," namely, declaring who they are not? ${ }^{23}$ Another important rabbi and religious authority, Jacob ben Asher, also from the fourteenth century, claimed that when women thank God who made them according to His will they express their acceptance of their hapless position. In fact, when uttering their blessing, women say, "What can we do? This is the way that God made

19 T. Ross, op. cit., pp. 37-38.

${ }^{20}$ A testimony of an Orthodox rabbi about how women in his community and his female students were deeply upset and wounded by the blessing, see: A. Weiss, SheLo Asani Isha: An Orthodox Rabbi Reflects on Integrity, Continuity, and Inclusivity, "Conversations" 2013, no. 16, pp. 151-153.

${ }^{21}$ Ibidem, p. 149.

${ }^{22}$ A. Weinrot, Feminism ve-yahadut, Tel Aviv 2001, pp. 119-120 (Hebrew).

${ }^{23}$ A. Weiss, op. cit., p. 150. 
us. ${ }^{24}$ Five hundred years later in Germany, Rabbi Samson Raphael Hirsch confirmed that indeed men are grateful for not having been made a woman because they must fulfil all the mitzvoth, whereas women are exempted from some of the mitzvoth not because they do not have time, as Abudirham argued, but because they do not need them; women are much more faithful and devoted than men. ${ }^{25}$ According to this approach, it seems that the commandments are restricting tools for men who are not as religiously dedicated as women. The apologetic character of this argument is clear. It claims that men are grateful for not being made a woman because they are less devoted and fervent than women, and therefore, the mitzvoth are perceived as guidelines for weak characters. This kind of reasoning expresses the need to reconcile between the problematic blessing and modern perceptions which recognise women as full human beings, and defiantly not inferior. Rabbi Hirsch added that women bless God "for having made me according to His will," to thank Him for being different from men, having different roles, and being more spiritual skilled, and thus, not obliged by all the mitzvoth. ${ }^{26}$ The nineteenth-century rabbi from Lviv, Jacob Meshulam Ornstein also sympathised with this apologetic propensity, claiming that women tend to $\sin$ less than men, and thus do not have to be chained by all the mitzvoth. ${ }^{27}$ Nowadays, Rabbi Eliezer Melamed claims that men were created from earth, while women were created from a subtler material, namely the man's rib, and therefore one can conclude that women are much more advanced in their spiritual development. ${ }^{28}$ Rabbi Eliyahu Munk ${ }^{29}$ added that women express in their blessing - for having made me according to His will - their deep gratitude, because being exempted from most of the mitzvoth means a divine trust in its highest ethical meaning. Interestingly, this approach is quite popular in contemporary religious writings, especially those of an educational character, and deal with the status of women in Judaism. ${ }^{30}$ Still, the morning blessings are an act of gratitude of a person who is healthy, whose basic needs are satisfied, and who is a Jew. Being a Jew means being a person who belongs to the community, who has a Jewish way of life, who prays, and most importantly, studies the Torah and keeps all the mitzvoth. Taking into consideration the fact that Jewish women are exempted from the last two important elements, I believe that the conclusion that a woman cannot be a full Jew is unavoidable. This assertion has been appropriate for traditional-normative Judaism over the ages, and is for the Orthodox, particularly Ultra-Orthodox communities today.

Women were not satisfied with these arguments, and although some rabbis claimed that they were closer to God and spiritually superior, they could not feel privileged and satisfied with their blessing. In some siddurim (prayer books) from

${ }^{24}$ D. Sperber, On Changes in Jewish Liturgy: Option and Limitations, Jerusalem 2010, p. 33.

25 A. Weinrot, op. cit., p. 122.

${ }^{26}$ Ibidem, pp. 123-124.

${ }^{27}$ Ibidem, pp. 125-126.

${ }_{28}$ A. Melamed,Hilkhotbirkhotha-shahar,http://www.yeshiva.org.il/midrash/1947[access: 15.04.2017] (Hebrew).

${ }^{29}$ Kaliningrad 1900-Jerusalem 1978.

${ }^{30}$ G. Zivan, op. cit., pp. 14-15. 
the fourteenth and fifteenth centuries, one can find other versions, for example "for being made a woman and not a man," or just "for being made a woman." Here there is a positive assertion of what a woman is, and not a passive acceptance of God's verdict. Being a woman has some positive aspects and meaning. ${ }^{31}$ In another version, "for being made Israelite," one can find a confirmation of self-identity, ${ }^{32}$ except that the gender element is lacking here, and in these siddurim men still thank for not having been made a woman. We do not know whether these alternative blessings were invented by women or by men. We also do not know when they were first written, but all the sources were written by men. ${ }^{33}$ A simple and clear example for the previous modification of the blessing is the version in a siddur from the fifteenth century written in Italy by Abraham Farissol, a scribe who wrote siddurim for wealthy women. A siddur from 1480 states: "Blesse are You ... Who did not make me a handmaiden. Blesse are You ... Who made me a woman and not a man. Blesse are You ... Who did not make me a Gentile woman." ${ }^{34}$

In contrast to the apologetical explanations, there were also interpretations of very important rabbis, such as the medieval Spanish rabbi Joshua ibn Shuaib and the twentieth-century great spiritual leader and rabbi Abraham Yitshak Ha-Kohen Kuk, who thought that the blessings reflected reality. He believed that in the world there is a clear metaphysical superiority of men over women. Furthermore, the male soul is active, law-making, conquering, eliminating, while the female soul is passive, conquered and defeated by men. ${ }^{35}$ It is worth mentioning that the contemporary rabbi Eliezer Waldenberg ${ }^{36}$ also holds the same view regarding the essentialist inferiority of women. ${ }^{37}$ This essentialist approach grasps the inferiority of women as an ontological fact, a hierarchy that no educational and social efforts may change. Nevertheless, this view is rather unpopular among modern religious commentators, since it is impossible to prove its metaphysical hypotheses. ${ }^{38}$

\section{Modernity: Varied strategies}

From the nineteenth century, European Jews' unease with the blessing increased. Consequently, they used different tactics to cope with the problem. Three strategies were and still are the most common: repentance or apologetic interpretations, removing or ignoring the text, and modifying it. ${ }^{39}$ It is important to underline that in

${ }^{31}$ Y.H. Kahn, Barukh she'asani isha [in:] D.Y. Ariel, M. Leibowotz, Y. Mazor, Baruch she'asani isha?, Tel Aviv 1999, pp. 125-126.

32 A. Lavi, Tefilat Nashim, Tel Aviv 2005, pp. 32-33.

33 Y.H. Kahn, Barukh she'asani isha, op. cit., p. 123.

${ }^{34}$ D. Sperber, op. cit., pp. 41-44.

${ }_{35}$ S. Riskin, op. cit., pp. 142-143.

${ }^{36}$ Jerusalem 1915-Jerusalem 2006.

${ }^{37}$ G. Zivan, op. cit., p. 12.

${ }^{38}$ Ibidem, p. 13.

39 Y.H. Kahn, Barukh she'asani isha, op. cit., p. 126. 
traditional rabbinic Judaism it is clearly forbidden to ignore or modify an obligatory blessing. Nevertheless, there were some rabbis who suggested not uttering the blessings in public. ${ }^{40}$ In some modern siddurim, the blessing is omitted. For example, in two prayer books - one from 1975, in English (Hebrew-English) and of the Reform movement, ${ }^{41}$ and the other from 1997, in German (Hebrew-German) and of the Progressive movement ${ }^{42}$ - I have found that the whole of the morning blessings is omitted. A moderate version of omitting was to recite the blessing silently, as a "sign of sensitivity to the feelings of others, if not an ideal solution." ${ }^{43}$ However, Jewish communities did not accept silent prayer in the place of the morning blessings on a large scale. ${ }^{44}$ The ideal solution for those who feel offended by the blessing would have been its disappearance from the prayer book. Daniel Sperber mentions other blessings that with time were omitted, or fell out of use and disappeared from the liturgy. And these changes were implied in traditional normative Judaism for generations, and not only in modern and progressive communities. Therefore, there is no hindrance to the same happening with shelo asani isha..$^{45}$

On an interesting Hebrew-language website for Christians, the blessings are modified in such a way that they do not contain gender difference. There are two blessings which are uttered by men and women together: שעשני בצלמו - who made me in His Image, and שעשני כרצונו - who made me according to His will. ${ }^{46}$ Interestingly, some reform congregations adopted a similar solution and decided that men and women would pronounce the same blessing: "for making me in His own image." ${ }^{47}$

Some of the recent versions, which try to preserve the gender differences, suggest that a woman should say "for making me a woman" and a man "for making me a man," or renounce the three blessings and instead utter "for making me the daughter/ son of Israel." ${ }^{48}$ This is the solution that Hagai Ben-Artsi suggests for the traditional version of the blessing. His argument is that taking into consideration that women today are considered equal not only in their roles but also in their value and spiritual level to men, and women do study the Torah in some Orthodox communities, ${ }^{49}$ the traditional version is problematic and reflects the view that women are inferior. $\mathrm{He}$ finds legal support for his version in the Talmud itself (Menahot, 43:72) where, according to Rabbi Meír, instead of saying "for not having made me a gentile (nonJew)" a Jew should say in the affirmative manner "for having made me an Israelite."

${ }^{40}$ G. Zivan, op. cit., p. 18.

${ }^{41}$ Gates of Prayer, the New Union Prayer Book, Central Conference of American Rabbis, New York 1975.

42 Seder Ha-Tefilot: Das Jüdische Gebetbuch, J. Magonet, H. Walter (eds.), Gütersloh 1997.

${ }^{43}$ D. Sperber, op. cit., pp. 38-39.

${ }^{44}$ G. Zivan, op. cit., p. 18.

${ }^{45}$ Ibidem, pp. 39-40.

${ }^{46}$ Ivrit le-notsrim, Birchot HaShahar, http://www.hebrew4christians.com/Blessings/Synagogue Blessings/Birchot_HaShachar/birchot_hashachar.html [access: 15.04.2017].

${ }^{47}$ Y.H. Kahn, Barukh she'asani isha, op. cit., p. 127.

48 Ibidem.

${ }^{49}$ Modern Orthodoxy tends to adopt the approach of the Talmudic scholar Ben-Azzai, who claimed that "a man ought to teach his daughter Torah." Sota 3, 20:1. 
This version does not pronounce disrespect for gentiles, but rather joy and gratefulness for being a part of the Jewish world. However, for Ben-Artsi, it is important to keep gender differences together with gender equality, and therefore, he suggests that men should say "for making me the son of Israel," and women "for making me the daughter of Israel." $" 50$

Another version which holds equality between the genders together with keeping the gender difference is that men should say "for having made me a man (and not a woman)," and women "for having made me a woman (and not a man)." A similar version appeared even in siddurim from the fourteenth and fifteenth centuries in Italy, so from the legal point of view there is a halakhic precedence which enables its acceptance. ${ }^{51}$ Daniel Sperber notes an important detail: the Orthodox rabbi and the theologian Abraham Berliner from nineteenth-century Germany claimed that if the version שעשני ישראל - who has made me an Israelite, which appears in some sources, were to prevail and become the norm in all Jewish communities, it would be the simplest solution. This version makes the three blessings superfluous, and in that way, all discriminating or insulting nuances towards others would disappear. Berliner showed that Jews made alteration and modifications in canonical texts through the ages, and therefore, this alteration is totally justified, even according to the strictest form of Judaism..$^{52}$ Moreover Halakha - the Jewish law - is a living organism that takes into consideration tradition but also the needs of a given era, namely, the present state of mind and culture of Jews in each situation. ${ }^{53}$

It is worth mentioning that even today, modern Jewish rabbis and scholars who are part of Ultra-Orthodox and Orthodox congregations oppose any modification to the Jewish prayer book very strongly. ${ }^{54}$ Vociferous discussions are continuing to take place, however ${ }^{55}$ Modernised Jewish movements solved this problem, and, in fact, they have also solved the general issue of the status of women in their communities, introducing an egalitarian approach. However, the morning prayer is still a very challenging issue for the Orthodox Jewish discourse. Mostly, the arguments repeat the same views from Abudirham to Rabbi Kuk, but the debate clearly shows that this blessing is still a source of unease in the traditional Jewish world. But even among the Orthodox, as we saw in the case of Rabbi Weiss, there are some exceptions. Another religious leader, the modern Orthodox rabbi Shlomo Riskin, admitted that the male benediction reflects the inferior status of women in Judaism, and therefore offered

${ }^{50}$ H. Ben-Artsi, Birkat shelo asani isha: ha-im yesh alternative?, "Akdamot” 1998, no. 4, pp. 129 130 (Hebrew).

${ }^{51}$ G. Zivan, op. cit., pp. 19-20.

${ }^{52}$ D. Sperber, op. cit., pp. 45-46. This approach is also supported by the contemporary Orthodox rabbi Avraham Weiss, who sees in it a solution to the pain of women hearing the blessing. See: A. Weiss, op. cit., p. 153.

${ }^{53}$ A. Weiss, op. cit., p. 154.

${ }^{54}$ A.A. Frimer, Feminism and Changes in Jewish Liturgy, "Hakirah, The Flatbush Journal of Jewish Law and Thought" 2011, no. 12, pp. 65-87.

55 There are many Orthodox websites on which various rabbis continue to grapple with this issue, usually after being asked by religious individuals. It might be said that this is the modern continuations of the Jewish tradition of Responsa. 
an egalitarian wording, which, in his opinion, does not negate the original sense of those who formulated the benedictions. In the new version, men should say "for not being made a woman, and being made according to His will," and women should bless "for being made according to His will and not being made a man." gument for the legitimacy of modifying the blessings is a socio-historical one. As mentioned above, the Jewish version of the three blessings is based on, or inspired by, the Greek blessing. This fact shows how Judaism was always influenced by other cultures. Therefore, there is no obstacle to take into consideration our social perceptions, our culture, and our zeitgeist, with women being considered equal human beings, and consequently, to modify the blessings. ${ }^{57}$

Sperber believes that a change is possible and is legally justified. Changes in the Jewish liturgy always happened; some were minor and other were major, as entire new blessings and prayers. ${ }^{58}$ Therefore, changing the morning blessing has its justification in normative Judaism, and there is no halakhic obstacle for that. Sperber adds that "the rabbis felt free to exercise in formulating new liturgical elements when they saw an urgent need for it." 59 The question which remains is ethical, and is connected to a basic human skill - empathy: will Orthodox rabbis feel the pain and injury of women, and thus, finally, sense the urgent need for change?

\section{References}

Ben-Artsi H., Birkat shelo asani isha: ha-im yesh alternativa?, "Akdamot” 1999, no. 4, pp. 129130.

Elior R., Baruch ata adonai elohenu melekh ha-olam shelo asani isha, "Ravgoni" 2000, no. 3, pp. 30-35.

Elior R., Blessed Art Thou, Lord our God, Who Hast not Made Me a Woman [in:] Men and Women:

Gender, Judaism and Democracy, R. Elior (ed.), Jerusalem 2004, pp. 81-96.

Frimer A.A., Feminism and Changes in Jewish Liturgy, "Hakirah, The Flatbush Journal of Jewish Law and Thought" 2011, no. 12, pp. 65-87.

Gates of Prayer, the New Union Prayer Book, New York 1975.

Greenberg B., On Women and Judaism: A View from Tradition, Philadelphia 1981.

Ivrit le-notsrim, Birchot HaShahar, http://www.hebrew4christians.com/Blessings/Synagogue Blessings/Birchot_HaShachar/birchot_hashachar.html [access: 15.04.2017].

Kahn Y.H., Barukh she'asani isha [in:] D.Y. Ariel, M. Leibowotz, Y. Mazor, Baruch she'asani isha?, Tel Aviv 1999, pp. 121-128.

Kahn Y.H., The Three Blessings: Boundaries, Censorship, and Identity in Jewish Liturgy, Oxford 2011.

Kehat H., Haye'ha ha-meyusarim shel Rayna-Batya Berlin, http://www.old.kolech.org.il/maamar/ page/36/ [access: 15.04.2017].

Lavi A., Tefilat Nashim, Tel Aviv 2005.

MelamedA., Hilkhot birkhot ha-shahar, http://www.yeshiva.org.il/midrash/1947 [access: 15.04.2017].

\footnotetext{
56 S. Riskin, op. cit., pp. 141, 148-149.

${ }^{57}$ G. Zivan, op. cit., pp. 17-18.

${ }^{58}$ D. Sperber, op. cit., p. 51.

${ }^{59}$ Ibidem, p. 53.
} 
On Being a Jewish Feminist, S. Heschel (ed.), New York 1983.

Plaskow J., Standing Again at Sinai, New York 1990.

Riskin S., Birkat 'shelo asani isha', efsharuyot leshinuy [in:] M. Shilo, Lihiyot isha yehudiya, Jerusalem 2001, pp. 139-149.

Ross T., Expanding the Palace of Torah: Orthodoxy and Feminism, New Hampshire 2004.

Seder Ha-Tefilot: Das Jüdische Gebetbuch, J. Magonet, H. Walter (eds.), Gütersloh 1997.

Sperber D., On Changes in Jewish Liturgy: Option and Limitations, Jerusalem 2010.

Tabory J., The Benedictions of Self-Identity and the Changing Status of Women and of Orthodoxy [in:] J. Tabory, Kenishta: Studies of the Synagogue World, Bar-Ilan 2001, pp. 107-138.

Tsarfati O., Liran-Alper D., Baruch shelo asani isha? Nitsane si'ah nashi-feministi baitonut haharedit ha-misharit, "Kesher" 2010, no. 40, pp. 126-138.

Weinrot A., Feminism ve-yahadut, Tel Aviv 2001.

Weiss A., SheLo Asani Isha: An Orthodox Rabbi Reflects on Integrity, Continuity, and Inclusivity, "Conversations" 2013, no. 16, pp. 149-160.

Zivan G., 'Shelo asani isha' ve 'she'asani kirtsono': hatsa'a livrakha aheret [in:] M.D. Halpern, C. Safrai, Jewish Legal Writings by Women, Jerusalem 1998, pp. 5-25. 